\title{
GIVING IN AN ISLAMIC PERSPECTIVE
}

\author{
Mohamad Isa Abd. Jalil \\ Universiti Malaysia Sabah \\ Jalan UMS, 88400 Kota Kinabalu, Sabah, Malaysia \\ e-mail: isa@ums.edu.my
}

\begin{abstract}
The purpose of this study is to shed light on the underlying concept of giving in the perspective of Islam. Methodologically, this study employs qualitative systematic data processing approach. The conceptual framework is developed from the Quran, Hadith, and the story of the Prophet and his companions. This study also refers to a conventional theory such as Altruism, Socially Consumer Behaviour, and Social Exchange Theory. Several previous empirical studies were also recorded to support the proposition. This study proposes four variables that might influence people to give, namely, targhîb, tarhîib, ih $\underline{\text { sân }}$ and $i k h w a h$. By realizing many other factors that may influence the giving behaviour, this study only focuses on the Islamic religious perspective. This article also brought opportunities to investigate conceptually and empirically other factors that could affect giving behaviour. To the best of the author's information, there is only a small number of studies that have been done concerning the influence of religion towards giving behaviour. And it is at his juncture the novelty of this study lies.
\end{abstract}

\begin{abstract}
Abstrak: Penelitian ini berupaya menjelaskan konsep dasar dari "memberi" dalam perspektif Islam. Secara metodologis, penelitian ini menggunakan pendekatan pemrosesan data sistematis kualitatif. Kerangka konsep dikembangkan dari al-Qur'an, Hadis, dan kisah atau atsâr para sahabat Nabi Muhammad SAW. Kajian ini juga merujuk kepada teori konvensional seperti Altruism, Socially Consumer Behavior, dan teori Social Exchange. Beberapa kajian empirik sebelumnya juga dirujuk untuk mendukung proposisi tersebut. Penelitian ini mengemukakan empat variabel yang

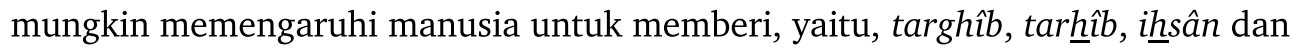
$i k h w a h$. Dengan menyadari faktor-faktor lain yang dapat memengaruhi perilaku memberi, penelitian ini hanya berfokus pada perspektif agama Islam. Artikel ini juga membawa peluang untuk menyelidiki secara konseptual dan empiris berbagai faktor lain yang dapat memengaruhi perilaku memberi. Sejauh pengetahuan penulis, hanya ada sejumlah kecil studi yang telah dilakukan mengenai pengaruh agama terhadap perilaku memberi. Di sinilah letak kebaruan dari penelitian ini.
\end{abstract}

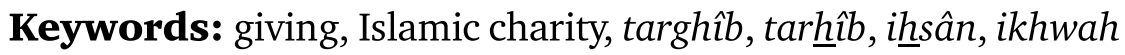




\section{Introduction}

During fine and terrible economic times, charitable donations have continued to move in primarily persistent over the past half-century. In a usual time, total charitable gifts of funds exceed 2 per cent of gross domestic product in the United States of America. ${ }^{1}$ In Malaysia, the amount of zakat collected for the entire state in Malaysia in 2010 was 1.36 billion ringgits. While Waqf, RM18 million were recorded in 2013 for a total sum in Malaysia. The number of the pool, although there are ups and downs, relatively it increased compared to a decade ago. The amount of zakat higher than the Waqf is not surprising because the Waqf is not mandatory as zakat.

Nevertheless, even the law of zakat is compulsory, regarding law enforcement, unlike income tax, people who refused to pay zakat still a high volume and not be punished. According to Manat, ${ }^{2}$ despite extensive provisions including provisions relating to offences and penalties, it cannot be fully enforced due to specific problems such as staff constraints, infrastructure, skills enforcement personnel and administrative structure of zakat is not as clear. Still, with weak enforcement and volunteer activities, the figure of the collection is quite high. There must be something that affects Muslims to give donations other than law enforcement.

The concept of giving in Islam which is originated from Arabic word tabarru' that means donation or gifts, is not something outlandish in the religious practices of Islam. There are numerous types of charity in Islam, with distinctive execution contexts, but with a shared purpose. Generally, there are five types of giving in Islam which include Zakah, Sadaqah, Hibah, Waqf, and al-Wasiyyah. Zakah is an Islamic religious "tax" charged to the wealthy and well-to-do members of the community for distribution to the poor and the needy as well as other beneficiaries based on specific established criteria according to the Qur'an. ${ }^{3}$ The main aim of zakat is to protect the socio-economic welfare of the poor and the needy. Shadaqah is a concept of giving only to the underprivileged and needy. ${ }^{4} \mathrm{Hibah}$ is an inclusive notion of giving to everyone, including the affluent and non-Muslims. ${ }^{5}$

${ }^{1}$ John A. List, "The Market for Charitable Giving," in Journal of Economic Perspectives, Vol. 25, No. 2, 2011, p. 157-180.

${ }^{2}$ Abu Bakar Manat, "Undang-Undang Dakwa Orang Ramai Enggan Bayar Zakat," in Utusan Online (Kuala Lumpur, 3 November 2006).; See generally Mhd. Syahnan, Modernization of Islamic Law of Contract (Jakarta: Badan Litbang \& Diklat Departemen Agama RI, 2009); also by the same author, Contemporary Islamic Legal Discourse: A Study of Sayyid Quthb's Fi Zhilal alQur'an (Medan: IAIN Press, 2010).

${ }^{3}$ Norazlina Abd. Wahab and Abdul Rahim Abdul Rahman, "A Framework to Analyse the Efficiency and Governance of Zakat Institutions," in Journal of Islamic Accounting and Business Research, Vol. 2, No. 1, 2011, p. 43-62.

${ }^{4}$ Wahbbah al-Zuhayli, Nazhâriyah al-Dharûrah al-Syar'iyyah Muqaranah Maa' al-Qanûn al-Wadhi (Damsyiq: Dâr Al-Fikr, 1997).

${ }^{5}$ Mohd Zamro Muda, "Instruments of Hibah and Wills: Analysis of the Regulations and 
Waqf is equivalent to the endowment and entails essential features that include the declaration of intention, the contributor, the property and the beneficiary. The main different characteristics of waqf are irrevocability, perpetuity, and inalienability. ${ }^{6}$ Finally, Al-Wasiyyah (last will) is a gift of property that arises from the death of a testator. ${ }^{7}$

The very foundation of giving system in Islam has an enormous impact and gave many contributions to society. As stated by Bidin, Idris, \& Shamsudin, ${ }^{8}$ the allocation of Zakah fund can benefit produce and stir the country's economic performances via an increase in individuals' purchasing power. This advocates that the advancement of the nation and the society could be executed dynamically if Zakah fund could be efficiently raised. According to Jalil and Muda, ${ }^{9}$ Sadaqah is being complementary funding shortfalls occurring in Zakat funds or other funds such as endowments and Sadaqah flexible and able to be used in various forms and sectors. Rusnadewi and Ahmad ${ }^{10}$ verify that Hibah is very beneficial because the administration can be made to suit the recipient economy.

Similarly, Waqf covers the areas of poverty relief projects, supports education development, improves health care sector, upholds the sustainability of Islam, aids the reduction of national debt, and promotes fiscal development. ${ }^{11}$ This significant impact must come from substantial and continuous contributions. Hence, this study tries to find out the possibility of Muslim motivation to give in the perspective of Islam.

The purpose of this study is to examine what are the factors that could influence Muslim to give from the perspective of Islam. Specifically, there is still no past study that similar with this article, to make a comparison, in terms of direct objective. However, with reference to the conceptualisation of why people donate, quite plenty. Abd Jalil, Yahya

Applications in Malaysia," in Hibah and Faraid National Convention (Kuala Lumpur: n.p. 2008), p. 1-42.

${ }^{6}$ Mohamad Tahir Sabit Mohammad and Abdul Hamid Mar Iman, "Obstacles of the Current Concept of Waqf to the Development of Waqf Properties and the Recommended Alternative," in Malaysian Journal of Real Estate, Vol. 1, No. 1, 2006, p. 27-38.

${ }^{7}$ Muda, "Instruments of Hibah and Wills: Analysis of the Regulations and Applications in Malaysia," p. 1-42.

${ }^{8}$ Zainol Bidin, et al., "Predicting Compliance Intention on Zakah on Employment Income in Malaysia: An Application of Reasoned Action Theory," in Jurnal Pengurusan, Vol. 28, No. 1, 2009, p. 85-102.

${ }_{9}^{9}$ Abdullaah Jalil and Muhamad Muda, "Pengurusan Dana Sedekah Secara Sistematik/ : Analisis Peranan Institusi Kerajaan dan Swasta," in Jurnal Pengurusan Jawhar, Vol. 2, No. 1, 2008, p. 53-72.

${ }^{10}$ Abdul Rasyid Rusnadewi and Nor Hisyam Ahmad, "Pengurusan Harta Melalui Hibah: Kepentingan dan Manfaat Dari Pelbagai," in Hadhari, Vol. 5, No. 1, 2013, p. 91-104.

${ }^{11}$ Farhana Mohamad Suhaimi, et al., "The Role of Share Waqf in the Socio-Economic Development of the Muslim Community: The Malaysian Experience," ed. Professor Masudul Alam Choudhury, Humanomics, Vol. 30, No. 3, 2014, p. 227-254. 
and Allah Pitchay, ${ }^{12}$ conceptualise the role of information disclosure to building committed waqif from the theory of Social Exchange. Vlaholias, Thompson, Every and Dawson ${ }^{13}$ suggest the factors behind the motivation to food donation based on the theory of Pro-Social Behaviour. Marko and Peter, ${ }^{14}$ in the other hands, conceptual a framework of giving based on 'nostalgia'. Due to Zakat, Waqf, Sadaqah, Hibah and Wasiyyah is related to religion; this study is interested in studying the factors that influence Muslims to donate according to Islamic perspective. Also, the motivation of this study came from the gap in the body of knowledge regarding how Islam urges their follower to give.

This article applies the method of the qualitative systematic data processing approach where the Quran, Hadith, and the story of the Prophet Muhammad PBUH companions is examined. Thematic analysis, often called Qualitative Content Analysis (QCA) in Europe, is one of the most commonly used methods for analysing qualitative data. There are five phases involved which are reading the data intensively, building the coding frame, coding the data, analysed the coded data, and presenting the results.

This study is expected to give a contribution predominantly in the theory development of giving from the perspective of the Islamic religion. The factor of religion has significantly proven affecting donor's intention to help. ${ }^{15}$ However, there has been no study that explains how Islam as religion encourages its followers to give charity. Thus, this article is foreseeable to fill this gap in the body of knowledge. Practically, the fundraiser can take advantage of this conceptual study model to understand better their donors and use it as one of their marketing strategies.

\section{Theoretical and Literature Review}

According to the theories of giving, there are many reasons why people give. Green and Webb ${ }^{16}$ said that charity behaviour is categorised into three motives: interpersonal motives, social motives, and economic motives. Based on these three categories, the charity behaviour theory can be separated into two: selfish and selfless. These summary is based

${ }^{12}$ Mohamad Isa Abd Jalil, et al., "Building Committed Waqif: The Role of Information Disclosure," in Journal of Islamic Accounting and Business Research, Vol. 10, No. 2, 2019, p. 185-215.

${ }^{13}$ Elisha Vlaholias et al., "Charity Starts ... at Work? Conceptual Foundations for Research with Businesses That Donate to Food Redistribution Organisations," in Sustainability (Switzerland), Vol. 7, No. 6, 2015, p. 7997-8021.

${ }^{14}$ Sarstedt Marko and Schloderer Matthias Peter, "Developing a Measurement Approach for Reputation of Non-Profit Organizations," in International Journal of Nonprofit and Voluntary Sector Marketing, Vol. 15, No. 1, 2010, p. 276-299.

${ }^{15}$ Jacob Boersma and Gijs Burgers, Dealing with Digital Donations Platforms (Netherland: n.p., 2013).

${ }^{16}$ C.L. Green and D.J. Webb, "Factors Influencing Monetary Donations to Charitable Organizations," in Journal of Nonprofit \& Public Sector Marketing, Vol. 5, No. 3, 1997, p. 19-40. 
on numerous theory of giving existed such as The Negative State Model, ${ }^{17}$ Altruism, ${ }^{18}$ Theory Social Responsibility, ${ }^{19}$ The Theory of Social Exchange, ${ }^{20}$ Social Conformity, ${ }^{21}$ Financial Ability, ${ }^{22}$ and Tax Incentive. ${ }^{23}$

Empirically, there are dozens of factors that influence the intention to donate among donors. One of the reasons why people donated is because of a religious factor. A surveybased on personal interviews that have been carried out every year since 1985 to 1997 by Schlegelmilch, Diamantopoulos, and Love ${ }^{24}$ with aims to provide information about individual giving and volunteering in Britain has found out that individuals who think religion is important are more likely to be donors. Amos ${ }^{25}$ summarise into seven broad groups of motives underlying individual contributions to charity, and one of the reasons is to seek religious benefit. Serrano, Gallen and Molnero ${ }^{26}$ finds divergent patterns of giving that reflect alternative sources of donor identity, such as religion, ethnicity, and gender, and explains why certain kinds of donors are more or less likely to diverge from the prestige hierarchy of their class in their philanthropy. Teah, Lwin and Cheah ${ }^{27}$ investigated the moderating effects of religious beliefs on attitudes towards charities and motivation to donate and was found that religious beliefs moderate the relationship between attitudes

${ }^{17}$ Robert B Cialdini, et al., "Insights from Sadness: A Three-Step Model of the Development of Altruism as Hedonism," in Developmental Review, Vol. 1, No. 3, 1981, p. 207-223.

${ }^{18}$ Auguste Comte, The Catechism of Positive Religion, John Chapman (Cambridge: Cambridge University Press, 1891).

${ }^{19}$ Leonard Berkowitz, "Social Norms, Feelings, and Other Factors Affecting Helping and Altruism,"in Advances in Experimental Social Psychology, Vol. 6, No. C, 1972, p. 63-108.; Syahnan, Mhd. "Islam as a System: A Critical Analysis of Sayyid Quthb's Principle Thought," in Analytica Islamica, Vol. 4 No. 1, May 2002, p. 45-57.

${ }^{20}$ George C. Homans, "Social Behavior as Exchange," in American Journal of Sociology, Vol. 63, No. 6, 1958, p. 597-606; Peter Blau, Exchange and Power in Social Life (New York: Wiley, 1964).

${ }^{21}$ Solomon E. Asch, "Effects of Group Pressure on the Modification and Distortion of Judgments.," in H. Guetzkow (ed.), Groups, Leadership and Men (Pittsburgh, PA: Carnegie Press, 1951), p. 177-190.

${ }^{22}$ Louis De Alessi, "Toward an Analysis of Postdisaster Cooperation," in American Economic Review, Vol. 65, No. 1, 1975, p. 127-138.

${ }^{23}$ Gary S Becker, "A Theory of Social Interactions?," in Journal of Political Economy, Vol. 82, No. November/December, 1974, p. 1063-1093.

${ }^{24}$ Bodo B. Schlegelmilch, et al., "Characteristics Affecting Charitable Donations: Empirical Evidence from Britain," in Journal of Marketing Practice: Applied Marketing Science, Vol. 3, No. 1, 1997, p. 14-28.

${ }^{25}$ Orley M. Amos, "Empirical Analysis of Motives Underlying Individual Contributions to Charity," in Atlantic Economic Journal, Vol. 10, No. December, 1982, p. 45-32.

${ }^{26}$ Carlos Serrano-Cinca, et al., Measuring DEA Efficiency in Internet Companies, Decision Support Systems, Vol. 38 (United States of America: Princeton Academic Press, 2005).

${ }^{27}$ Min Teah, et al., "Moderating Role of Religious Beliefs on Attitudes Towards Charities and Motivation to Donate," in Asia Pacific Journal of Marketing and Logistics, Vol. 26, No. 5, 2014, p. 738-760. 
towards charities and motivation to donate. The influence of religion to charity donation also affecting the group from rich and wealthy people. ${ }^{28}$ Pharoah and Tanner ${ }^{29}$ has looked and the possible of causative of the trends in charitable giving from 1974 until 1994. They discovered that the percentage of giving fell 5 per cent and made deductions that three possibilities have caused the decline in giving, which is increasing income inequality, the decline in importance of religion, and recent changes in the role of charitable organisations. Therefore, empirically, the religious factor does affect donating action.

The closest theory that describing religious influence on charity donation is the Theory of Altruism. ${ }^{30}$ Altruism born from the concept of the Catechism of positive religion. He initially discussed the positive side of Christian theology, and one of them is Altruism. Altruism or selflessness is understood to be behaviour that benefits others at a personal cost to the behaving individual. ${ }^{31}$ It is a customary morality in many cultures and a heart feature of various religious traditions and secular worldviews, though the concept of "others" toward whom concern should be directed can vary among cultures and religions. According to Steinberg, ${ }^{32}$ in biological organisms, Altruism can be explained as a person carrying out an action which is at a sacrifice to themselves (e.g., leisure and quality of life, time, prospect of reproduction or survival), but advantages, either directly or indirectly, another third-party person, with no hope of mutual benefit or compensation for that action. Steinberg ${ }^{33}$ suggests a definition of altruism in the clinical setting that is "intentional and voluntary measures that aim to enhance the welfare of another person in the absence of any quid pro quo external rewards".

Nevertheless, doing for religion not necessarily means altruistic. Amos $^{34}$ discovered that there are a group of people who donate for the sake of religious benefit. In viewpoint Islam, the example of a spiritual interest is to enter paradise. According to Buddhism and Hinduism, one can get happiness and good life as a continuous succession of incarnations - a "wheel of life" (samsara) where individual beings undergo rebirth and re-death, relentlessly suffering according to their deeds. ${ }^{35}$ Although the concept of Altruism

${ }^{28}$ Theresa Lloyd, Why Rich People Give (UK: Association of Charitable Foundations, 2004).

${ }^{29}$ Cathy Pharoah and Sarah Tanner, "Trends in Charitable Giving," in Fiscal Studies, Vol. 18, No. 4, 1997, p. 427-443.

${ }^{30}$ Comte, The Catechism of Positive Religion, p. 22.

${ }^{31}$ Benjamin Kerr, et al., "What Is Altruism?," in Trends in Ecology and Evolution, Vol. 19, No. 3, 2004, p. 135-140.

${ }^{32}$ David Steinberg, "Altruism in Medicine: Its Definition, Nature, and Dilemmas," in Cambridge Quarterly of Healthcare Ethics, Vol. 19, No. 2, 2010, p. 249-257.

${ }^{33} \mathrm{Ibid}$.

${ }^{34}$ Amos, "Empirical Analysis of Motives Underlying Individual Contributions to Charity'.

35 Todd Lewis, "Altruism in Classical Buddhism," in Altruism in World Religions, ed. Jacob Neusner and Bruce D. Chilton (Washington: Georgetown University Press, 2005), p. 88. 
introduced by Comte ${ }^{36}$ is based on Christianity, but according to Downs, ${ }^{37}$ the idea of atoning almsgiving developed in large part as a result of nascent Christian engagement with scriptural traditions that present care for the poor as having the potential to secure future reward, including heavenly merit and even the cleansing of sin, for those who practice mercy. With the promise of a reward is taught, there may be people who give donations solely to the pursuit of the promised reward, and not for other's sake.

Still, to gain the reward as promised by religion, one must sacrifice something in the names of charity giving. Green and $\mathrm{Webb}^{38}$ categorised the behaviour of charity giving to get something as "selfish" which is opposite of altruism. The theory that able to explain this phenomenon is Social Exchange Theory (SET). SET was founded by Homans ${ }^{39}$ and Blau, ${ }^{40}$ where posits that human relationship is formed by the use of subjective cost-benefit analysis and the comparison of alternatives. According to McDonell, Gottfried, Burton, and Yaffe, ${ }^{41}$ People who are engaged in interaction are rationally seeking to maximise profits. When interacting with others, individuals seek to maximise profits for themselves while minimising costs. Because it is not possible to know the actual rewards and expenses involved in interacting with another before interactions occur, individuals, guide their behaviour through their expectations for rewards and costs. ${ }^{42} \mathrm{Blau}^{43}$ proposed that in his Basic Philanthropy Model, gratitude from beneficiaries and social approval from peers are the reward for giving charity donation.

Based on the theories discussed, it is understood that the behavioural of giving might because of altruism, care for others and may also due to seeking benefit for themselves. As this study objective is to try to find out the possibility of Muslim motivation to give in the perspective of Islam, the primary source of Islam will be referred. The main sources of reference to Islam following the main sequence are the first Quran, the Hadith, Ijma' (a consensus of Islamic scholars) third and fourth Qiyas (analogy). ${ }^{44}$

${ }^{36}$ Comte, The Catechism of Positive Religion, p. 23.

${ }^{37}$ D.J. Downs, Alms: Charity, Reward, and Atonement in Early Christianity, Alms: Charity, Reward, and Atonement in Early Christianity (Baylor University Press, 2016).

${ }^{38}$ Green and Webb, "Factors Influencing Monetary Donations to Charitable Organizations.

${ }^{39}$ Homans, "Social Behavior as Exchange.

${ }^{40}$ Blau, Exchange and Power in Social Life.

${ }^{41} \mathrm{~J}$. McDonell et al., "Behaviorism, Social Learning, and Exchange Theory," in S. P. Robbins, P. Chatterjee, and E. R. Canda, Contemporary Human Behavior Theory: A Critical Perspective for Social Work (Pearson, 2006).

${ }^{42}$ Ronald M. Sabatelli and Constance L. Shehan, "Exchange and Resource Theories," in Sourcebook of Family Theories and Methods, Vol. 53 (Boston, MA: Springer US, 1993), p. 385417.

${ }^{43}$ Blau, Exchange and Power in Social Life.

${ }^{44}$ Abd Halim Mohd Noor, et al., "Performance Indicators Model for Zakat Institution," in Jurnal Pengurusan JAWHAR, Vol. 1, No. 2, 2007, p. 71-84. 


\section{Targhib}

Etymologically, the word targhib is originated from Arabic word 'raghaba' meaning please and love. Then it turned into a noun targhib which implies an expectation of obtaining pleasure, love, and happiness..$^{45}$ All were raised in the form of promises of beauty and joy that can stimulate a person who raised hope and encouragement to acquire it. Psychologically, it could cause a strong appeal to reach it. In the Quran and Hadith, there are many chapter and verse that urge human to do good things, including giving by promises a reward. For example;

"Who is it that would loan Allah a goodly loan (give their wealth in the way of Allah) so He may multiply it for him many times over? And it is Allah who withholds and grants abundance, and to Him, you will be returned" (Q.S. al-Baqarah/2: 245).

"The example of those who spend their wealth in the way of Allah is like a seed [of grain] which grows seven spikes; in each spike is a hundred grains. And Allah multiplies [His reward] for whom He wills. And Allah is all-Encompassing and Knowing" (Q.S. al-Baqarah/2: 261).

"Believe in Allah and His Messenger and spend out of that in which He has made you successors. For those who have believed among you and spent, there will be a great reward" (Q.S. al-ㅍaîd/57: 7).

The Messenger of Allah PBUH said: "Whoever gives charity equal to a date from good (halal) earnings - for Allah does not accept anything but that which is good - Allah will take it in His right hand and tend it for the one who gave it as anyone of you tends his foal, until it becomes like a mountain."

It is narrated by al-Bukhârî, 1344; Muslim, 1014.

The Messenger of Allah PBUH said: "There is no day on which the people get up, but two angels come down, and one of them says, 'O Allah, give in compensation to the one who spends (in charity),' and the other says, 'O Allah, destroy the one who withholds"

Narrated by al-Bukhârî, 1374; Muslim, 1010.

The concept of targhib will motivate a person to donate to seek a reward in the Hereafter. A Muslim also promised to get the help of God in the world when giving donations from the hadith "And God will help a servant for the servant helps his brother" (Narrated by Muslim). Although a person might provide a charity because they want to help the beneficiaries, but primarily, they are motivated by the reward offered. This phenomenon is quite similar to the Social Exchange Theory that stated that an individual expected

${ }^{45}$ Syahidin, Metode Pendidikan Qur'ani Teori Dan Aflikasi (Jakarta: Misaka Galiza, 1999). 
a reward when donating. In the book of consumer motivation, Dichter ${ }^{46}$ claimed that people give to acquire power and to obtain satisfaction by pleasing parent figure.

Imam Dhahabi in his book Tarikhul Islam as cited by Al-Basya, ${ }^{47}$ during the rule of Umar al-Khattab, the Prophet PBUH companion names Sa'id bin Amir was a governor in Syria, and he was destitute so much to the extent he only has one pair of cloth. One day, Umar al-Khattab offered Sa'id bin Amir a thousand Dinars to relieve his acute poverty. When the money was received, Said's wife was delighted. She immediately advised the husband saying: "Praise be to Allah SWT who has enriched us out of your service. Buy some provision for the home and also get us a home help." To this Sa'id bin Amir replied: "Is there not a better way to spend this? Let us spend it on whoever comes to us in need, and we will get something better for it by investing in this way." Said's wife immediately gave her approval. The noble Sa'id then shared out the money into small bags instructing his children and other members of the family to give them out to the widows, orphans and other needy ones until every dinar was invested towards the lasting and promising life in the Hereafter.

During the war of Tabuk (9 years after Hijra), the weather was hot, and the fighting was expected to be very tough. The Prophet PBUH made an open declaration that the Muslims should gather in strength and prepare adequately to face the forces of the Roman Empire. He also encouraged them to contribute towards the equipment of the expedition for the sake of reward from Allah. ${ }^{48}$ It was on this occasion that Abu Bakr contributed all his belongings. When the Prophet PBUH questioned him as to what he had left for his family, he replied: "I have left Allah and His Rasul for them." Umar al-Khattab contributed half his belongings, and 'Uthman al-Affan provided for the equipment of one-third of the whole army. ${ }^{49}$

Empirically, there are quite numbers of study that support the concept of targhib. Margolis ${ }^{50}$ found that political gains and tax incentive do motivate people to donate. This finding is backed up by Green and Webb. ${ }^{51}$ In the perspective of gift-giving in anthropological, the motives for giving may range from agonistic, where the donors attempt to maximise personal gain or satisfaction, to altruistic, where donors try to maximise the pleasure of

${ }^{46}$ E. Dichter, Dichter's Dream Book: Handbook of Consumer Motivations (New York: McGrawHill, 1964).

${ }^{47}$ Abdurrahman Ra'fat al-Basya, Kisah Heroik 65 Orang Sahabat Rasulullah SAW (Jakarta: Kuwais International, 2008).

${ }^{48} \mathrm{Ibid}$.

${ }^{49}$ Sallam April, Sejarah Lengkap Kehidupan Rasulullah Shalallahu 'Alaihi Wa Sallam (Kuala Lumpur, Malaysia: Al-Hidayah Publication, 2015).

${ }^{50} \mathrm{H}$. Margolis, Selfishness, Altruism, and Ratiormlity (Cambridge: Cambridge University Press, 1982).

${ }^{51}$ Green and Webb, "Factors Influencing Monetary Donations to Charitable Organizations'. 
the recipient. ${ }^{52}$ Dawson ${ }^{53}$ discover that career advancement and income advantages did motivate charitable giving. Some people seeking a reward such as recognition from the charity and social awards like new friendship and increased the sense of community from donation contribution. ${ }^{54}$ At least, according to Broadbridge and Horne,${ }^{55}$ one of the reasons people involve in charity retailing is to meet people and make friends. Based on the above discussion, we propose;

P1: The more people know about the reward of giving in Islam, the more people intend to give.

\section{Tarhib}

Meanwhile, the word 'tarhib' comes from the Arabic word 'rahhaba' meaning frighten or threaten. Then it turned into a noun "tarhib" which means that the threat of punishment. ${ }^{56}$ Tarhib is a threat or punishment as a result of the detrimental act of sin or mistake which is prohibited by Allah SWT. Alternatively, delay in carrying out the obligations ordered by Allah SWT. ${ }^{57}$ Tarhib usually involves compulsory matter in Islam such as Salah, Zakah, fasting in the month of Ramadan, and pilgrimage. However, when it consists of a practice that is encouraged but not mandatory such as dhikr, fasting every Monday, and Sadaqah, the concept of tarhib very rarely applied because people who do not practice it, not the sinner. The example of ayah in the Quran and hadith regarding tarhib is as follow;

"And let not those who [greedily] withhold what Allah has given them of His bounty ever think that it is better for them. Rather, it is worse for them. Their necks will be encircled by what they witheld on the Day of Resurrection. And to Allah belongs the heritage of the heavens and the earth. And Allah, with what you do, is [fully] acquainted." (Q.S. Ali 'Imran/ 3: 180).

"Oyou who have believed, indeed many of the scholars and the monks devour the wealth of people unjustly and avert [them] from the way of Allah. And those who hoard gold

${ }^{52}$ John F. Sherry, "Gift Giving in Anthropological Perspective," in The Journal of Consumer Research, Vol. 10, No. 2, 1983, p. 157-168.

${ }^{53}$ Scott Dawson, "Four Motivations for Charitable Giving: Implications for Marketing Strategy to Attract Monetary Donations for Medical Research," in Journal of Health Care Marketing, Vol. 8, No. 2, 1988, p. 31-37.

${ }^{54}$ Joseph R. Mixer, Principles of Professional Fundraising: Useful Foundations for Successful Practice (San Francisco, California: Jossey-Bass Publishers, 1993).

${ }^{55}$ Adelina Broadbridge and Suzanne Horne, "Who Volunteers for Charity Retailing and Why," in The Service Industries Journal, Vol. 14, No. 4, 1994, p. 421-437.

${ }^{56}$ Syahidin, Metode Pendidikan Qur'ani Teori dan Aflikasi.

${ }^{57}$ Muhammad Nashîruddîn al-Albani, Shahîh al-Targhîb wa al-Tarhîîb (Riyâdh: Maktabah al-Ma'arif, 2000). 
and silver and spend it not in the way of Allah - give them tidings of a painful punishment." (Q.S. al-Tawbah/9: 34).

Narrated Abu Huraira: Allah's Apostle said, "Anyone whom Allah has given wealth but he does not pay its Zakat, then, on the Day of Resurrection, his wealth will be presented to him in the shape of a bald-headed poisonous male snake with two poisonous glands in its mouth, and it will encircle itself round his neck and bite him over his cheeks and say, "I am your wealth; I am your treasure." Then the Prophet recited this Divine Verse: "And let not those who covetously with hold of that which Allah has bestowed upon them of His Bounty." (3.180) Shahîh Bukhârî - (Book 60, Hadith 88).

Narrated Abu Dhar: Once I went to him (the Prophet) and he said, "By Allah in Whose Hands my life is (or probably said, 'By Allah, except Whom none has the right to be worshipped) whoever had camels or cows or sheep and did not pay their Zakat, those animals will be brought on the Day of Resurrection far bigger and fatter than before and they will tread him under their hooves, and will butt him with their horns, and (those animals will come in circle): When the last does its turn, the first will start again, and this punishment will go on till Allah has finished the judgments amongst the people." Shahîh Bukhârî - (Book 24, Hadith 539).

When Muslim's realised that they would be punished if they do not pay Zakah, they will be motivated to give in the form of zakat. As far as author concern, there is still no empirical literature about the influence of tarhib in giving. Though, there are previous studies have indicated that people give because of fear. Dichter ${ }^{58}$ stated one of the giving motivation is fear. $\operatorname{Amos}^{59}$ said that people give because they worry society might disapproval them if they not give. In other research, negative motivations such as anxiety and insecurity are the factors why people give. ${ }^{60}$ Building on Lazarus's general theory of emotion and adaptation, Bagozzi and $\mathrm{Yi}^{61}$ hypothesise that public service ads designed to reduce the incidence of child abuse stimulate negative emotions; these, in turn, lead to empathic reactions and end with the decision to help. Bagozzi and $\mathrm{Yi}^{62}$ found out that people give because of fears that the incidence of child abuse might happen to them. Although all the empirical evidence does not mention anything about the consequences in the Hereafter, at least it proves that people did give because of the feeling of fear of something.

In the book of Bahrul Mazi written by Al-Marbawi, ${ }^{63}$ there is a story in the time of

${ }^{58}$ Dichter, Dichter's Dream Book: Handbook of Consumer Motivations.

${ }^{59}$ Amos, "Empirical Analysis of Motives Underlying Individual Contributions to Charity'.

${ }^{60}$ Mixer, Principles of Professional Fundraising: Useful Foundations for Successful Practice.

${ }^{61}$ Richard P. Bagozzi and Youjae Yi, "On the Evaluation of Structural Equation Models," in Journal of the Academy of Marketing Science, Vol. 16, No. 1, 1988, p. 74-94.

${ }^{62}$ Ibid.

${ }^{63}$ Muhnammad Idrîs 'Abd Rauf al-Marbawi, Mukhtasar Shaĥîh al-Turmudzi wa Syarhuhuhu 
Prophet Muhammad PBUH; there is a woman pray behind the Prophet Muhammad PBUH. Suddenly, she fainted because of fear when the Prophet recited the Quran about seven gates of hell. When she is conscious, she has freed seven slave's servant as a redeemer for every gate of hell. This incident proved that fear could lead to the behaviour of giving. Thus, based on the above discussion, we propose;

P2 :The more people know about the punishment of not giving in Islam, the more people intend to give.

\section{Ihsân}

In Islam, I $\underline{h} s \hat{a} n$ is the Muslim obligation to achieve flawlessness or excellence, in worship, for example, Muslims effort to worship God as if they see Him, and even though they not able to see God, they without a doubt believe that God is perpetually watching over them. That description derives from the Hadith of Jibril in which Muhammad PBUH states, "[Ihsân is] to worship God as though you see Him, and ifyou cannot see Him, then indeed He sees you". (al-Bukhârî and al-Muslim) ${ }^{64}$ Chittick ${ }^{65}$ explains Ihssân, denoting "to do beautiful things", is a one-third element of the Islamic religion which are Islam, Iman and Ihsân. In distinguishing to the stresses of Islam (what one should do) and Iman (why one should do), the view of Ihsân is principally related to intention. One is called a Muhsin when he/she does a beautiful deed. It is commonly understood that an individual can only reach true I $\underline{h} s a ̂ n$ with the help and guidance of God, who governs all things.

In the conventional theory of giving, the concept of Ihsân is had in common with the theory of Altruism. As the term Ihsân is originated from Islam, Altruism terminology is initiated from the religion of Christian. ${ }^{66}$ Leeds ${ }^{67}$ defines altruistic behaviour as an end in itself, not directed at a reward; emitted voluntarily, and doing good. Some rich people give because they have a passion for charity ${ }^{68}$ However, the empirical evidence on altruism is not consistent, and it is not surprising since, according to Dawkins, ${ }^{69}$ humans are born selfish. These days, psychology still holds to the idea that genuine altruism cannot be verified

Bi Lughah al-Jâwî al-Malayu al-Musammas Bahrul Mâzi (Kaherah, Mesir: Mathba'ah Musthâfâ Halabi wa Auladuh, 1933).

${ }^{64}$ Mahmoud M. Ayoub, Islam: Faith and History (UK: Oneworld Publications, 2004).

${ }^{65}$ William C. Chittick, Sufism: A Beginner's Guide (UK: Oneworld Publications, 2007).

${ }^{66}$ Comte, The Catechism of Positive Religion, p. 62.

${ }^{67}$ Ruth Leeds, "Altruism and the Norm of Giving," in Merrill-Palmer Quarterly, Vol. 9, Oktober 1963, p. 229-239.

${ }^{68}$ Beth Breeze, "Why Do Rich People Give?," Discover Society (Beth Breeze: University of Kent, 2013).

${ }^{69}$ Richard Dawkins, The Selfish Gene, New Scientist, Vol. 214 (UK: Oxford University Press, 2012). 
and is suitably justified through other egoistic models (e.g., reinforcement). ${ }^{70}$ Schlegemilch ${ }^{71}$ discover that the attitudes towards charity did not play a prominent role in the repeatedly carried out discriminant analysis.

Nevertheless, recorded by Bukhari and Muslim, there was one Prophet PBUH companion had a visitor, the companion asked his wife, and "Do you have something to entertain guests?" His wife replied, "No, just enough food for our children". Then the companion said, "Distract our children with something (encourage play), if they want dinner, encourage them to sleep. Moreover, when we are living in (the dining room), then extinguish the lights. Moreover, show him that we were eating with him". They sat together in the dining room while they slept in a state of starvation. When the morning, they went along to the Prophet PBUH and thereupon Prophet PBUH praise against them, "It is God impressed with both of you act towards your guests".

From the book of Tafseer Imam Ibn Kathir, Anas bin Malik says, "Abu Talhah owned the best gardens in Medina, and they were more in number than those of any other Ansari (an Islamic term for the local inhabitants of Medina who took the Islamic Prophet Muhammad PBUH and his followers (the Muhajirun) into their homes when they escaped from Mecca (hijra). One of his gardens was known by the name of Bir Ha, which was his most favourite resort. It was close to the Prophet PBUH mosque, and the water of its well was sweet and abundant. The Prophet PBUH often visited that garden and drank of the water. When Allah revealed the verse, "You will not attain piety untilyou spend of that which you love."(AliImran:92). Abu Talhah came to the Prophet PBUH presence and spoke out from his heart, "O, Nabi of Allah! I love Bir Ha very much. As Allah wants us to spend that which we love, I make over that garden to be spent in the path of Allah as you please." The Allah Apostle PBUH was delighted and remarked: "What a fine present (to Allah)! I think it would be best utilised if you distribute it among your own heirs." Based on the above discussion, we propose;

P3: The stronger a person faith in Islam, the more people intend to give.

\section{Ikhwah}

In the story of the companions of Prophet Muhammad PBUH, Ibn 'Umar said, "One of the companions of the Prophet PBUH was given a goat's head, he said, "Indeed so and so and their families need this more than we do". Ibn Umar said, "Then he sent the gift to the other, and continually gifts were sent from one person to another to rotate to seven houses, and finally back to the person who first gives"(Reported by al-Bayhaqi in ash Shu'ab

70 Todd D. Nelson, "Motivational Bases of Prosocial and Altruistic Behavior: A Critical Reappraisal," in Journal of Research, Vol. 4, No. 1, 1999, p. 23-31.

${ }^{71}$ Schlegelmilch, Diamantopoulos, and Love, "Characteristics Affecting Charitable Donations: Empirical Evidence from Britain". 
3/259). Al-Imam al-Nawawi in his book of Riyadhus Salihin, Abdullah record that ibn Mus'ab al-Zubaidi and Hubaib bin Abi Thabit, both were told, "Al-Harith bin Hisham, Ayyash bin Abu Jahl and Suhayl ibn Amr was martyred at Yarmuk. They are then given a drink while they are in critical condition, but all of them repel. When one of them is given to drink, he said, "Give the first to so and so", and so on until all of them died and they have not had time to drink it. In another version of the narrator recounts, "Ikrima asked for water to drink, and then he saw Suhail was looking at him, then Ikrima said," Give it to him. "And when it Suhail also see al-Harith was seen, and he said," Give it to him (al-Harith) ". But not until the water is to al-Harith, the three had died without a chance to feel the water. (Reported by Ibn Sa'd in Tabaqat).

When Abdur-Rahman arrived in Medina, he had no money and no property. He had to start from scratch. During the summer in $622 \mathrm{CE}$, about seventy Muslims set off with their families to Medina, where they were lodged in the houses of the Ansar, the Muslims of Medina until they could build their homes. Abdur-Rahman was paired up with Sa'ad Ibn Ar-Rabi'ah who was one of the wealthiest men of Medina. On that occasion, Sa'ad, out of generosity and kindness to his new brother, told Abdur-Rahman, "My brother, among the people of Medina I have the most wealth. I have two orchards, and I have two wives. See which of the two orchards you like, and I shall vacate it for you, and which of my two wives is pleasing to you, and I shall divorce her for you." This is the kind of love Muslims of the time had for each other. Sa'ad Ibn Ar-Rabi'ah was ready to part with his fortune and his family for the sake of Allah and brotherhood. ${ }^{72}$

Ikhwah (Brotherhood) in Islam is a far-reaching thought that is grounded upon decent personality with others, deal with others the way we want to be deal with, and bonding together over respective values. The deepest stage of brotherhood is the sense of friendship, community, and shared a purpose in Islam for the sake of Allah. At this point, the believers thrive together towards achieving the aspirations of the religion and living out its divine principals. As Allah said: "The believers are but brothers, so make reconciliation between

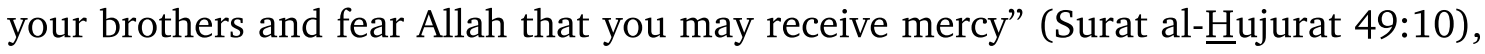
"Hold firmly to the rope of Allah all together and do not become divided. Remember the favour of Allah upon you, when you were enemies, and He brought your hearts together, and you became brothers by his favour" (Surat Âli 'Imrân 3:103), and "The believing men and believing women are allies of one another. They enjoin what is right and forbid what is wrong and establish prayer and give charity and obey Allah and His Messenger. Allah will have mercy upon them, for Allah is Almighty and Wise" (Surat al-Tawbah/ 9: 71).

In the theory of conventional, Sojka ${ }^{73}$ explained the theory of Socially Consumer

${ }^{72}$ Al-Basya, Kisah Heroik 65 Orang Sahabat Rasulullah SAW.

${ }^{73}$ Jane R. Ziegler Sojka, "Understanding Donor Behavior: A Classification Paradigm," in Advances in Consumer Research, Vol. 13, 1985, p. 240-245. 
Behaviour were closely related to altruism but with an awareness of societal needs is a category of behaviour directed towards society as a whole and exemplified by the "socially conscious consumer. Definitions of the socially conscious consumer vary according to the researcher. Nonetheless, they all accept that this type of behaviour is enacted to help others or bring about presumably beneficial social changes. Webster ${ }^{74}$ defines the socially conscious consumer as one "who takes into account the public consequences of his or her private consumption or who attempts to use his or her purchasing power to bring about social change. Amos ${ }^{75}$ and Margolis ${ }^{76}$ found out that peoples are giving because desiring to see others benefit. Broadbridge and Horne ${ }^{77}$ examines the demographic characteristics of the volunteer workforce for one particular charity chain and reports an analysis of its work patterns and motivations, discovered one of the reason is there is a friend in the shop. The image of familiarity is also proven significantly influenced helping behaviour. ${ }^{78}$ The concept brotherhood not necessarily to be based on religion or race; the sense of Ikhwah might come from the same regions. ${ }^{79}$ Sargeatn, Ford, and $\mathrm{West}^{80}$ has confirmed that, if there is a family bond the effect of the influence of donor commitment to donate is even greater. Based on the above discussion, we propose;

P4: The stronger a person senses of brotherhood, the more people intend to give Waqf agriculture.

\section{Conceptual Framework}

As stated in the section of theoretical and literature review, this conceptual paper is based on the Quran, Hadith, the story of Prophet PBUH companions, conventional theories and previous empirical evidence. According to the theory of Altruism by Comte ${ }^{81}$ and several past kinds of literature, people do give donation under the influence of religion. The conceptual framework in figure 1, portrays factors that encourage Muslims to give gifts from the perspective of Islam. Overall, there are four factors that Islam exploit to promote people to give which is Tarhib, Targhib, Ihsan and Ikhwah. Under the concept of

${ }^{74}$ Frederick E. Webster, Jr., "Determining the Characteristics of the Socially Conscious Consumer," in Journal of Consumer Research, Vol. 2, No. 3, 1975, p. 188.

${ }^{75}$ Amos, "Empirical Analysis of Motives Underlying Individual Contributions to Charity."

${ }^{76}$ Margolis, Selfishness, Altruism, and Ratiormlity.

77 Broadbridge and Horne, "Who Volunteers for Charity Retailing and Why".

${ }^{78}$ Neeli Bendapudi, et al., "Enhancing Helping Behavior: An Integrative Framework for Promotion Planning," in Journal of Marketing, Vol. 60, July 1996, p. 33-49.

${ }^{79}$ Schlegelmilch, et al., 'Characteristics Affecting Charitable Donations: Empirical Evidence from Britain'.

${ }^{80}$ Adrian Sargeant, et al., "Perceptual Determinants of Nonprofit Giving Behavior," in Journal of Business Research, Vol. 59, No. 2, 2006, p. 155-165.

${ }^{81}$ Comte, The Catechism of Positive Religion, p. 53. 
Tarhib, people will feel intimidated by the punishment of God will befall them if they do not pay zakat. There also have sinned, and fear of punishment from Allah for sins that have been committed, give donations for their sins forgiven. This study also proposes that the intention to give derived from the desire to seek a reward from Allah under the concept of Targhib. When people learned on the pleasure and reward promised by God, they will fill motivated to involve in charity.

In Islam, the highest level of sincerity is Ihsan. When people become Muhsin (individuals who achieve Ihsan), they no longer do worship as a reward or fear of punishment, but because of love and servitude to Allah. So, the attitude of altruism will grow stronger when their faith sturdier and lead to giving behaviour. Lastly, this study proposes the positive relationship between the factors of Ikhwah and giving behaviour. Under the concept of Ikhwah, when people have a strong sense of belonging to some group, they will try to help them.

\section{Conclusion}

This study set out to develop a conceptual model for giving from the standpoint of Islam. This study has examined the peer-reviewed literature on the theory of giving such as Altruism and the influenced of religion towards giving. On the one hand, the concept of giving in the general term spins around at least on the interpersonal motives, social motives, and economic motives. In the Islamic religion however, the principal concept is based on the Quran, Prophetic Traditions, as well as the story of his Companions. This study has proposed four (4) variables that might affect people to give that constitute targhîb (reward) tarhîb (fear) ihsân (altruism) and ikhwah (sense of belonging). These findings raised the critical of empirical evidence to prove this model. These findings contribute in several ways to our understanding of giving behaviour from the perspective of Islam and provide a basis for further research. These results make several contributions to the current literature and relevant to both practitioners and policymakers. The future empirical study can prove all propositions that have been proposed.

\section{References}

Abd. Jalil, et al.. "Building Committed Waqif: The Role of Information Disclosure," in Journal of Islamic Accounting and Business Research, Vol. 10, No. 2, 2019.

Abd. Wahab, Norazlina and Abdul Rahim Abdul Rahman. "A Framework to Analyse the Efficiency and Governance of Zakat Institutions," in Journal of Islamic Accounting and Business Research, Vol. 2, No. 1, 2011.

Al-Albani, Muhammad Nashîruddîn. Shahîh al-Targhîb wa al-Tarhîb. Riyâdh: Maktabah al-Ma'rif, 2000. 
Al-Basya, Abdurrahman Ra'fat. Kisah Heroik 65 Orang Sahabat Rasulullah SAW. Jakarta: Kuwais International, 2008.

Al-Marbawi, Muhammad Idrîs 'Abd Rauf. Mukhtashar Shaĥhㅡ al-Turmudzi wa Syarhuhu Bi Lughah al-Jâwî al-Malayu al-Musammas Bahrul Mâzi. Kaherah, Mesir: Matba'ah Musthâfâ Halabi wa Auladuh, 1933.

Al-Zuhayli, Wahbah. Nazhâriyah al-Dharûrah al-Syar'iyyah Muqaranah Maa' al-Qanûn al-Wadhi. Damsyiq: Dâr Al-Fikr, 1997.

Amos, Orley M. "Empirical Analysis of Motives Underlying Individual Contributions to Charity," in Atlantic Economic Journal, Vol. 10, No. December, 1982.

April. Sallam, Sejarah Lengkap Kehidupan Rasulullah Shalallahu Alaihi Wa Sallam. Kuala Lumpur, Malaysia: Al-Hidayah Publication, 2015.

Asch, Solomon E. "Effects of Group Pressure on the Modification and Distortion of Judgments.," in H. Guetzkow Ed., Groups, Leadership and Men Pittsburgh. PA: Carnegie Press, 1951.

Ayoub, Mahmoud M. Islam: Faith and History. UK: Oneworld Publications, 2004.

Bagozzi, Richard P. and Youjae Yi. "On the Evaluation of Structural Equation Models," in Journal of the Academy of Marketing Science, Vol. 16, No. 1, 1988.

Becker, Gary S. "A Theory of Social Interactions?," in Journal of Political Economy, Vol. 82, November/December, 1974.

Bendapudi, Neeli, et al.. "Enhancing Helping Behavior: An Integrative Framework for Promotion Planning," in Journal of Marketing, Vol. 60, July 1996.

Berkowitz, Leonard. "Social Norms, Feelings, and Other Factors Affecting Helping and Altruism," in Advances in Experimental Social Psychology, Vol. 6, No. C, 1972.

Bidin, Zainol, et al.. "Predicting Compliance Intention on Zakah on Employment Income in Malaysia: An Application of Reasoned Action Theory," in Jurnal Pengurusan, Vol. 28, No. 1, 2009.

Blau, Peter. Exchange and Power in Social Life. New York: Wiley, 1964.

Boersma, Jacob, and Gijs Burgers. Dealing with Digital Donations Platforms. Netherland: n.p., 2013.

Breeze, Beth. "Why Do Rich People Give?," Discover Society. Beth Breeze: University of Kent, 2013.

Broadbridge, Adelina, and Suzanne Horne. "Who Volunteers for Charity Retailing and Why," in The Service Industries Journal, Vol. 14, No. 4, 1994.

Chittick, William C. Sufism: A Beginner's Guide. UK: Oneworld Publications, 2007.

Cialdini, Robert B., et al. "Insights from Sadness: A Three-Step Model of the Development of Altruism as Hedonism," in Developmental Review, Vol. 1, No. 3, 1981.

Comte, Auguste. The Catechism of Positive Religion, John Chapman. Cambridge: Cambridge University Press, 1891. 
Dawkins, Richard. The Selfish Gene, New Scientist, Vol. 214. UK: Oxford University Press, 2012.

Dawson, Scott. "Four Motivations for Charitable Giving: Implications for Marketing Strategy to Attract Monetary Donations for Medical Research," in Journal of Health Care Marketing, Vol. 8, No. 2, 1988.

De Alessi, Louis. "Toward an Analysis of Postdisaster Cooperation," in American Economic Review, Vol. 65, No. 1, 1975.

Dichter, E. Dichter's Dream Book: Handbook of Consumer Motivations New. York: McGrawHill, 1964.

Downs, D.J. Alms: Charity, Reward, and Atonement in Early Christianity, Alms: Charity, Reward, and Atonement in Early Christianity. Baylor University Press, 2016.

Green, CL, and DJ Webb. "Factors Influencing Monetary Donations to Charitable Organizations," in Journal of Nonprofit \& Public Sector Marketing, Vol. 5, No. 3, 1997.

Homans, George C. "Social Behavior as Exchange," in American Journal of Sociology, Vol. 63, No. 6, 1958.

Jalil, Abdullaah, and Muhamad Muda. "Pengurusan Dana Sedekah Secara Sistematik: Analisis Peranan Institusi Kerajaan Dan Swasta," in Jurnal Pengurusan Jawhar, Vol. 2, No. 1, 2008.

Kerr, Benjamin, et al. "What Is Altruism?," in Trends in Ecology and Evolution, Vol. 19, No. 3, 2004.

Leeds, Ruth. "Altruism and the Norm of Giving," in Merrill-Palmer Quarterly, Vol. 9, Oktober 1963.

Lewis, Todd. "Altruism in Classical Buddhism," in Jacob Neusner and Bruce D. Chilton (ed.), Altruism in World Religions. Washington: Georgetown University Press, 2005.

List, John A. "The Market for Charitable Giving," in Journal of Economic Perspectives, Vol. 25, No. 2, 2011.

Lloyd, Theresa. Why Rich People Give UK: Association of Charitable Foundations, 2004.

Manat, Abu Bakar. "Undang-Undang Dakwa Orang Ramai Enggan Bayar Zakat," in Utusan Online. Kuala Lumpur, 3 November 2006.

Margolis, H. Selfishness. Altruism, and Ratiormlity. Cambridge: Cambridge University Press, 1982.

Marko, Sarstedt, and Schloderer Matthias Peter. "Developing a Measurement Approach for Reputation of Non-Profit Organizations," in International Journal of Nonprofit and Voluntary Sector Marketing, Vol. 15, No. 1, 2010.

McDonell, J. et al. "Behaviorism, Social Learning, and Exchange Theory," in S. P. Robbins, P. Chatterjee, and E. R. Canda, Contemporary Human Behavior Theory: A Critical Perspective for Social Work. Pearson, 2006.

Mixer, Joseph R. Principles of Professional Fundraising: Useful Foundations for Successful Practice San Francisco. California: Jossey-Bass Publishers, 1993. 
Mohammad, Mohamad Tahir Sabit and Abdul Hamid Mar Iman. "Obstacles of the Current Concept of Waqf to the Development of Waqf Properties and the Recommended Alternative," in Malaysian Journal of Real Estate, Vol. 1, No. 1, 2006.

Muda, Mohd Zamro. "Instruments of Hibah and Wills: Analysis of the Regulations and Applications in Malaysia," in Hibah and Faraid National Convention. Kuala Lumpur: n.p. 2008.

Nelson, Todd D. "Motivational Bases of Prosocial and Altruistic Behavior: A Critical Reappraisal," in Journal of Research, Vol. 4, No. 1, 1999.

Noor, Abd Halim Mohd., Rozman Md Yusof, and Ahmad Che Yaakob. "Performance Indicators Model for Zakat Institution," in Jurnal Pengurusan Jawhar, Vol. 1, No. 2, 2007.

Pharoah, Cathy, and Sarah Tanner. "Trends in Charitable Giving," in Fiscal Studies, Vol. 18, No. 4, 1997.

Rusnadewi, Abdul Rasyid, and Nor Hisyam Ahmad. "Pengurusan Harta Melalui Hibah: Kepentingan dan Manfaat Dari Pelbagai," in Hadhari, Vol. 5, No. 1, 2013.

Sabatelli, Ronald M., and Constance L. Shehan. "Exchange and Resource Theories," in Sourcebook of Family Theories and Methods, Vol. 53. Boston, MA: Springer US, 1993.

Sargeant, Adrian, et al.. "Perceptual Determinants of Nonprofit Giving Behavior," in Journal of Business Research, Vol. 59, No. 2, 2006.

Schlegelmilch, Bodo B. et al., "Characteristics Affecting Charitable Donations: Empirical Evidence from Britain," in Journal of Marketing Practice: Applied Marketing Science, Vol. 3, No. 1, 1997.

Serrano-Cinca, Carlos, Yolanda Fuertes-Callén, and Cecilio Mar-Molinero. Measuring DEA Efficiency in Internet Companies, Decision Support Systems, Vol. 38. United States of America: Princeton Academic Press, 2005.

Sherry, John F. "Gift Giving in Anthropological Perspective," in The Journal of Consumer Research, Vol. 10, No. 2, 1983.

Sojka, Jane R. Ziegler. "Understanding Donor Behavior: A Classification Paradigm," in Advances in Consumer Research, Vol. 13, 1985.

Steinberg, David. "Altruism in Medicine: Its Definition, Nature, and Dilemmas," in Cambridge Quarterly of Healthcare Ethics, Vol. 19, No. 2, 2010.

Suhaimi, Farhana Mohamad, et al., "The Role of Share Waqf in the Socio-Economic Development of the Muslim Community: The Malaysian Experience," ed. Professor Masudul Alam Choudhury, Humanomics, Vol. 30, No. 3, 2014.

Syahidin. Metode Pendidikan Qur'ani Teori dan Aflikasi. Jakarta: Misaka Galiza, 1999.

Syahnan, Mhd. "Islam as a System: A Critical Analysis of Sayyid Quthb's Principle Thought," in Analytica Islamica, Vol. 4 No. 1, May 2002.

Syahnan, Mhd. Contemporary Islamic Legal Discourse: A Study of Sayyid Quthb's Fi Zhilal al-Qur'an. Medan: IAIN Press, 2010. 
MIQOT Vol. 44 No. 1 January-June 2020

Syahnan, Mhd. Modernization of Islamic Law of Contract. Badan Litbang \& Diklat Departemen Agama RI, 2009.

Teah, Min, et al. "Moderating Role of Religious Beliefs on Attitudes Towards Charities and Motivation to Donate," in Asia Pacific Journal of Marketing and Logistics, Vol. 26, No. 5, 2014.

Vlaholias, Elisha. et al. "Charity Starts ... at Work? Conceptual Foundations for Research with Businesses That Donate to Food Redistribution Organisations," in Sustainability Switzerland, Vol. 7, No. 6, 2015.

Webster, Jr., Frederick E. “Determining the Characteristics of the Socially Conscious Consumer," in Journal of Consumer Research, Vol. 2, No. 3, 1975. 